Bashar Jabbar Ali Al-Sahlanee, D. V. Lytkin, I. V. Senyuk

National University of Pharmacy

\title{
THE STUDY OF THE PHARMACOLOGICAL ACTION OF THE DRY EXTRACT FROM PRUNUS DOMESTICA FRUITS ON THE MODEL OF COMORBID FUNCTIONAL CONSTIPATION IN THE COMBINED ALCOHOLIC LIVER DAMAGE IN RATS
}

\begin{abstract}
The search for the most effective hepatoprotective agents is a topical issue of modern medicine. As a rule, the plant raw material is a promising object for studying medicinal properties. Based on the literature data, we are interested in the horticultural crop of Prunus domestica, the family Rosaceae, which is sufficiently cultivated and attracts attention by its pharmacoeconomic component.

Aim. In the previous experimental studies, the Prunus domestica extract containing fibers was found to have the laxative, hepatoprojector and probiotic effects. The foregoing facts provided an opportunity to study the Prunus domestica extract containing fibers for activity in comorbidization of some relevant pathologies and experimentally substantiate the prospects of its application as a medicine of choice for constipation in patients with pathologies of the digestive system.
\end{abstract}

Materials and methods. The study object was the dry extract from Prunus domestica fruits containing fibers. The experiment was performed in stages. At the first stage, the experimental subacute alcoholic liver damage was caused in animals. At the second stage of the experiment, functional constipation was modeled in animals. In the course of subacute hepatosis and during the second phase of the experiment animals were introduced the test extract in the dose of $200 \mathrm{mg} / \mathrm{kg}$ and the reference drug - a hepatoprotector Silybor in the dose of $25 \mathrm{mg} / \mathrm{kg}$. At the second stage of the study, a laxative Senadexin in the dose of $14 \mathrm{mg} / \mathrm{kg}$ was added to the therapy. All substances were introduced orally into the body of the experimental animals. To assess the motor activity of the intestine, the method of Sagar et al, modified by Choi et al., was used. The motor activity of the small intestine was determined according to the corresponding calculation formula. The functional state of the liver was assessed by the biochemical parameters in the blood serum: the total protein, urea and ALT activity.

Results. The analysis of the experimental data has shown that the test extract exhibits a moderate laxative effect. In animals of the intact group, the relevant signs (a pronounced laxative effect) indicate the development of diarrhea, which is not an adequate solution to the development of constipation. When using the extract from Prunus domestica fruits during the whole period of the experiment the normalization of all indicators characterizing the intestinal motility was observed. The analysis of the experimental data has demonstrated that the phytoobject studied has a soft laxative effect, mainly due to the improvement of the intestinal motility. When studying the functional state of the liver against the background of the introduction of the extract studied the positive changes in the content of markers of liver damage (decrease in the urea concentration and decrease in the activity of ALT in the animal serum) were detected compared to the control pathology group of animals No. 2 .

Conclusions. The experimental data obtained on the study of the correlation mechanisms of the hepatoprotective and laxative activity of the extract from Prunus domestica fruits containing fibers indicate the presence of a soft laxative effect that occurs by intensifying the intestinal motility, as well as the pronounced hepatoprotective action. These effects of the extract studied were revealed when using it in the treatment of constipation against the background of the experimental subacute liver damage, thus not being inferior the effects studied in the complex application of the hepatoprotective and laxative reference drugs. The key conclusion is that the extract studied, in contrast to the reference drug Senodexin, does not cause signs of diarrhea in its laxative effect, which can be a distinctive, positive feature in further clinical studies. This herbal object can be promising and rational when using it with the single-stage complex therapy as a hepatoprotective and laxative agent in the treatment of comorbid conditions in gastroenterology associated with diseases of the liver and congestive intestinal phenomena.

Key words: Prunes Domestica fruits; hepatoprotectors; comorbid fuctional constipation; subacute liver damage; urea; ALT

\section{Башар Джабар Алі Аль-Сахлані, Д. В. Литкін, І. В. Сенюк \\ Національний фармацевтичний університет}

\section{Дослідження фармакологічної дії сухого екстракту плодів Сливи на моделі коморбідизованого функціонального запору на тлі комбінованого алкогольного ураження печінки у щурів}

Пошук найбільш ефективних гепатопротекторних засобів $є$ актуальною проблемою сучасної медицини. Як правило, перспективними об'єктами для вивчення лікувальних властивостей є рослинна сировина. Згідно з літературними даними нас зацікавила садова культура Слива домашня (лат. Prunus domestica), сімейства Rosaceae, яка достатньо культивована і також привертає увагу своєю фармакоекономічною складовою.

Мета дослідження. У попередніх експериментальних дослідженнях екстракт Сливи домашньої, що містить волокна, були встановлені послаблювальний, гепатопротекторний і пробіотичний ефекти. Вищезазначене надало можливість дослідити екстракт Сливи домашньої, що містить волокна, на активність при коморбідизації 
кількох відповідних патологій і експериментально обгрунтувати перспективу його застосування в якості засобу вибору при запорах у пацієнтів з патологіями травної системи.

Матеріали та методи. Об'єктом досліджень був обраний сухий екстракт плодів Сливи домашньої, що містить волокна. Експеримент проводили поетапно. На першому етапі у тварин викликали експериментальне підгостре алкогольне ураження печінки. На другому етапі експерименту у тварин моделювали функціональний запор. У період перебігу підгострого гепатозу та впродовж другої фази експерименту тваринам вводили досліджуваний екстракт у дозі 200 мг/кг і препарат порівняння вітчизняний гепатопротектор силібор у дозі 25 мг/кг. У другій фазі досліджень приєднували до терапії проносний засіб сенадексин у дозі 14 мг/кг. Усі субстанції вводили до організму піддослідним тваринам перорально. Для оцінювання рухової активності кишечника використовували метод Sagar et al., модифікований за Choi et al. Моторну активність тонкого кишечника визначали за відповідною розрахунковою формулою. Функціональний стан печінки оцінювали за біохімічними показниками в сироватці крові: вміст загального білка, сечовини і активності АлАТ.

Результати. Аналіз експериментальних даних показав, що досліджуваний екстракт проявляє помірну послаблювальну дію. У тварин інтактної групи відповідні ознаки (виразний послаблювальний ефект) вказують на розвиток діареї, що не є адекватним вирішенням розвитку запорів. При використанні екстракту плодів Сливи домашньої впродовж усього періоду експерименту спостерігалася нормалізація усіх показників, що характеризують моторику кишечника. Аналіз експериментальних даних показав, що досліджуваний фітооб'єкт надає помірну послаблювальну дію переважно через поліпшення моторики кишечника. При дослідженні функціонального стану печінки на тлі введення досліджуваного екстракту Сливи домашньої були виявлені позитивні зміни вмісту маркерів пошкодження печінки (зменшення концентрації сечовини і зниження активності АлАТ у сироватці крові тварин) у порівнянні з групою тварин контрольної патології № 2.

Висновки. Отримані експериментальні дані з вивчення кореляційних механізмів гепатопротекторної і послаблювальної активності екстракту плодів Сливи домашньої, що містить волокна, свідчать про наявність помірного послаблювального ефекту, який реалізується за допомогою посилення моторики кишечника, а також про наявність виразної гепатопротекторної дії. Зазначені ефекти досліджуваного екстракту виявлені при його використанні у терапії запорів на тлі експериментального підгострого ураження печінки, при цьому не поступаючись досліджуваним ефектам при комплексному застосуванні гепатопротекторного і послаблювального препаратів порівняння. Ключовим висновком є той факт, що досліджуваний екстракт, на відміну від препарату порівняння сенодексину, при послаблювальній його дії не викликав ознак діареї, що може бути відмінною, позитивною рисою для подальших клінічних досліджень. Зазначений у дослідженнях рослинний об'єкт може бути перспективним і раціональним у застосуванні з одномоментною комплексною терапією як гепатопротекторний і послаблювальний засіб при лікуванні коморбідних станів у гастроентерології, пов'язаних із захворюваннями печінки та застійними явищами у кишечнику.

Ключові слова: плоди Сливи домашньої; гепатопротектори; коморбідний функціональний запор; підгостре ураження печінки; сечовина; АлАТ

\section{Башар Джабар Али Аль-Сахлани, Д. В. Лыткин, И. В. Сенюк}

Национальный фармацевтический университет

\section{Исследование фармакологического действия сухого экстракта плодов Сливы на модели коморбидного функционального запора на фоне комбинированного алкогольного поражения печени у крыс}

Поиск наиболее эффективных гепатопротекторных средств является актуальной проблемой современной медицины. Как правило, перспективными объектами для изучения лечебных свойств является растительное сырье. Исходя из литературных данных нас заинтересовала садовая культура Слива домашняя (лат. Prunus domestica), семейства Rosaceae, которая достаточно культивируемая, а также привлекает внимание своей фармакоэкономической составляющей.

Цель исследования. В предыдущих экспериментальных исследованиях экстракт Сливы домашней, который содержит волокна, были установлены слабительный, гепатопротекторный и пробиотический эффекты. Вышеизложенное дало возможность исследовать экстракт Сливы домашней, содержащий волокна, на активность при коморбидизации нескольких соответствующих патологий и экспериментально обосновать перспективу его применения в качестве средства выбора при запорах у пациентов с патологиями пищеварительной системы.

Материалы и методы. Объектом исследований был выбран сухой экстракт плодов Сливы домашней, содержащий волокна. Эксперимент проводили поэтапно. На первом этапе у животных вызывали экспериментальное подострое алкогольное поражение печени. Во втором этапе эксперимента у животных моделировали функциональный запор. В период течения подострого гепатоза и на протяжении второй фазы эксперимента животным вводили исследуемый экстракт в дозе 200 мг/кг и препарат сравнения отечественный гепатопротектор силибор в дозе 25 мг/кг. Во второй фазе исследований присоединяли к терапии слабительное средство сенадексин в дозе 14 мг/кг. Все субстанции вводили в организм подопытных животных перорально. Для оценивания двигательной активности кишечника использовали метод Sagar et al, модифицированный по Choi et al. Moторную активность тонкого кишечника определяли по соответствующей расчетной формуле. Функциональное состояние печени оценивали по биохимическим показателям в сыворотке крови: содержании общего белка, мочевины и активности АлАТ.

Результаты. Анализ экспериментальных данных показал, что исследуемый экстракт проявляет умеренное слабительное действие. У животных интактной группы соответствующие признаки (выраженный слабительный эффект) указывают на развитие диареи, что не является адекватным решением развития запоров. При использовании экстракта плодов Сливы домашней на протяжении всего периода эксперимента наблюдалась нормализация всех показателей, которые характеризуют моторику кишечника. Анализ экспериментальных данных 
показал, что исследуемый фитообъект оказывает мягкое слабительное действие преимущественно через улучшение моторики кишечника. При исследовании функционального состояния печени на фоне введения исследуемого экстракта Сливы домашней были обнаружены положительные изменения содержания маркеров повреждения печени (уменьшение концентрации мочевины и снижение активности АлАТ в сыворотке крови животных) в сравнении с группой животных контрольной патологии № 2.

Выводы. Полученные экспериментальные данные по изучению корреляционных механизмов гепатопротекторной и слабительной активностей экстракта плодов Сливы домашней, содержащий волокна, свидетельствуют о наличии мягкого слабительного эффекта, который реализуется с помощью усиления моторики кишечника, а также о наличии выраженного гепатопротекторного действия. Указанные эффекты исследуемого экстракта выявлены при использовании его в терапии запоров на фоне экспериментального подострого поражения печени, при этом не уступая изучаемым эффектам при комплексном применении гепатопротекторного и слабительного препаратов сравнения. Ключевым выводом является тот факт, что исследуемый экстракт, в отличие от препарата сравнения сенодексина, при слабительном его действии не вызывал признаков диареи, что может быть отличительной, положительной чертой при дальнейших клинических исследованиях. Данный растительный объект может быть перспективным и рациональным в применении с одномоментной комплексной терапией как гепатопротекторное и слабительное средство при лечении коморбидных состояний в гастроэнтерологии, связанных с заболеваниями печени и застойными явлениями в кишечнике.

Ключевые слова: плоды Сливы домашней; гепатопротекторы; коморбидный функциональный запор; подострое поражение печени; мочевина; АлАТ

$\mathrm{T}$ he search for the most effective hepatoprotective agents is a topical issue of modern medicine. As a rule, the plant raw material is a promising object for studying medicinal properties [1]. Based on the literature data, we are interested in the horticultural crop of Prunus domestica, the family Rosaceae, which is sufficiently cultivated and attracts attention by its pharmacoeconomic component $[2,3]$.

In the previous studies, the qualitative and quantitative chemical composition of the Prunus domestica fruits was determined. The presence of anthocyanins, rutin, gallic acid, sugars, organic acids (malate, citrate, chlorogenic, neochlorogenic, carboxylic acids), dietary fibers and hydroxycinnamic acids in the raw material was proven. [4-7].

Since in the previous experiments the dry extract from Prunus domestica fruits containing fiber (DECF) demonstrated the presence of both the hepatoprotective and laxative effects, it was expedient to study its activity in comorbidization of some relevant pathologies and experimentally substantiate the prospects of its application as a medicine of choice for constipation in patients with pathologies of the hepatobiliary system $[8,9]$.

It should be noted that functional constipation is often observed in patients with liver disease, namely alcoholic and non-alcoholic fatty liver disease, liver toxicity, liver failure, liver fibrosis and cirrhosis; in turn, this constipation is a factor in the progression of the underlying disease and adversely affects on the quality of life of such patients [10-13].

\section{Materials and methods}

Experimental animals. The study was conducted on 40 white non-linear male rats with the body weight of 200-220 g randomized to minimize differences in the body weight according to the EU Council Directive 2010/63/EU on compliance with the laws, regulations and administrative provisions of the EU Member States on the protection of animals used for experimental and other scientific pur- pose [14]. Prior to the experiment, the animals were kept under standard conditions in the Central Research Laboratory of the National University of Pharmacy (NPhU) in natural daylight and day-night mode with free access to water and food [15].

The experiment design. Animals were evenly divided into 5 experimental groups $(n=8)$ according to the following design scheme of the experiment:

- the first group - animals without any pathology during the experiment (intact control (IC));

- the second group - animals without liver pathology at the first stage of the experiment, but induced functional constipation at the second stage (control pathology No. 1 (CP-1));

- the third group - animals with induced liver pathology at the first stage of the experiment and induced functional constipation at the second stage (control pathology No. 2 (CP-2));

- the fourth group - animals with induced liver pathology at the first stage of the experiment and induced functional constipation at the second stage (test group). As treatment within the experiment these animals received DECF;

- the fifth group - animals with induced liver pathology at the first stage of the experiment and induced functional constipation at the second stage (reference group (RG). As a treatment the animals received Silybor as a hepatoprotector and Senedaxin as a laxative.

At the first stage of the experiment the experimental subacute combined alcoholic liver damage was induced in animals of the corresponding experimental groups. Animals from the corresponding groups, in which the pathology was modeled, were subcutaneously injected $50 \%$ oily solution of tetrachloromethane in the dose of $4 \mathrm{ml} / \mathrm{kg}$ for 4 days, followed by the intravenous injection of $40 \%$ aqueous ethanol solution in the dose of $13 \mathrm{ml} / \mathrm{kg}$ in 3 hours. During the induction of this model the hepatoprotectors studied were administered 1 hour before the introduction of hepatotoxins. Synergy with combined administration of tetrachloromethane 
and ethanol allows inducing a steady damage of the liver parenchyma, which is similar to chronic alcoholic hepatosis, in the short term $[14,15]$. The advantage of the subacute liver damage model compared to the chronic and subchronic ones in this case is in avoiding alcohol-associated diarrhea with the prolonged use of ethanol, which could affect the interpretation of the results of the second stage of the experiment [16].

During the second stage of the experiment, functional constipation was induced in animals by daily intragastric administration of loperamide hydrochloride (PhC "Zdorovya", Ukraine) in the dose of $3 \mathrm{mg} / \mathrm{kg}$ for 6 days 1 hour prior to the introduction of the test samples. Loperamide-induced retention of feces in the large intestine in rats is equivalent to the state of spastic constipation and corresponds to functional constipation with a decrease in peristalsis and absorption of fluid in humans $[17,18]$.

During induction of subacute hepatosis and the second stage of the experiment animals were treated with hepatoprotectors, which were administered daily for 10 days at 10:00-11:00. As in the previous experiments, the hepatoprotector Silybor (PhC "Zdorovya", Ukraine) was used as a reference drug in the dose of $25 \mathrm{mg} / \mathrm{kg}$, which was equivalent to $\mathrm{ED}_{30}$ of this medicine [19]. Since in the previous studies the maximum hepatoprotective effect of DECF was demonstrated in the dose of $200 \mathrm{mg} / \mathrm{kg}$, in this experiment a similar dose was used to obtain both specific effects. At the second stage of the experiment the rats of the reference group received aditionally Senadexin (PHC "LUBNIFARM", Ukraine) in the dose of $14 \mathrm{mg} / \mathrm{kg}$ (calculated with reference to the content of calcium sennosides A and B). The animal-equivalent dose was calculated from the average daily dose for humans, the interspecies weight difference, and the body surface area [20]. Taking into account the lack of data on the drug interaction of both reference drugs both samples were administered within one period $(10.00-11.00)$ in order to maintain equal conditions of the experiment; however, due to the phased introduction of medications between receiving drugs it took 30 minutes. In addition, such administration regimen allows us to reproduce the peculiarities of the patients' compliance in polypragmasy against the background of comorbid states [21].

All drugs studied in this experiment were dissolved or suspended in $1 \mathrm{ml}$ of purified water and injected with a special metallic enteral probe. Animals of control groups received the corresponding amount of physiological saline solution.

On day 5 of the administration of loperamide fecal boluses of rats were collected, and their parameters were determined. The day before, animals were placed in individual cages with free access to food and drinking water according to the hygienic requirements of the experiment. After collecting feces from each animal the day before the average number was calculated, and the moisture content was determined. Boluses were dried in a dry oven until a complete evaporation of moisture. The percentage moisture content was calculated according to the formula:

$$
C_{m}(\%)=\left[\left(M_{m}-M_{d}\right) / M_{m}\right] \times 100,
$$

where $\mathrm{C}_{\mathrm{m}}$ - is the fecal water content, $\%$; $\mathrm{M}_{\mathrm{m}}$ - is the fecal wet mass, $\mathrm{g}$;

$M_{d}$ - is the fecal dry mass, $g$.

18 hours before the last administration of the drugs studied animals were deprived of free access to food, but consumption of drinking water remained ad libitum. To assess the motor activity of the intestine in rats, the method proposed by Sagar et al., modified by Choi et al., and adapted for this species of laboratory animals $[17,22]$ was used. In $10 \mathrm{~min}$ after the last administration of the samples all animals were given a black contrast mass in the form of $3 \%$ suspension of activated charcoal in $0.5 \%$ aqueous methylcellulose solution of $1 \mathrm{ml}$ per animal.

In $30 \mathrm{~min}$ after the introduction of the contrast mass animals were euthanized by decapitation under inhalation anesthesia, their blood was collected to obtain the serum, the body was dissected, and the small intestine was removed from the pyloric sphincter to the caecum. The intestine was unfolded into a straight line, its total length, as well as the distance that the contrast mass passed, were measured. The motor activity of the small intestine was determined by the percentage indicator of the distance of the contrast mass accumulation according to the formula:

$$
\mathrm{L}_{\%}(\%)=\left(\mathrm{L}_{\mathrm{p}} / \mathrm{L}_{\mathrm{t}}\right) \times 100,
$$

where $\mathrm{L}_{\%}$ - is the indicator of the relative distance that the contrast mass passed, \%;

$\mathrm{L}_{\mathrm{t}}$ - is the total length of the small intestine, $\mathrm{cm}$.

$\mathrm{L}_{\mathrm{p}}$ - is the path passed by the contrast mass along the intestine, $\mathrm{cm}$.

Together with this, the colon was removed in animals, and the total number of fecal boluses remained in the lumen of the intestine was measured.

The condition of the liver was assessed by biochemical parameters in the blood serum - the content of total protein, urea, and alanine aminotransferase (ALT) activity were determined. These indicators allow assessing the functional state of the liver in relation to its main functions (protein synthesizing, detoxifying), as well as the degree of damage.

The content of total protein in the serum was determined quantitatively by the Biuret method using the standard set of reagents "Total protein (Biuret with a calibrator)" HP010.01 "Filitsit-Diagnostika", Ukraine) according to the instructions for use. 
Parameters of the daily defecation of the experimental animals with subacute liver damage against the background of loperamide-induced constipation (day 5), $\mathrm{M} \pm \mathrm{m}$

\begin{tabular}{|l|c|c|c|c|}
\hline \multicolumn{1}{|c|}{ Experimental group $(\mathrm{n}=8)$} & $\begin{array}{c}\text { The number } \\
\text { of fecal boluses }\end{array}$ & $\begin{array}{c}\text { The fecal wet } \\
\text { mass, } \mathrm{g}\end{array}$ & $\begin{array}{c}\text { The fecal dry } \\
\text { mass, } \mathrm{g}\end{array}$ & \% of water \\
\hline Intact control & $32.1 \pm 3.2$ & $6.51 \pm 0.64$ & $3.98 \pm 0.44$ & $39.50 \pm 2.27$ \\
\hline Control pathology No. 1 & $21.5 \pm 2.6^{*}$ & $4.48 \pm 0.29^{*}$ & $3.31 \pm 0.21$ & $25.93 \pm 1.31^{*}$ \\
\hline Control pathology No. 2 & $18.5 \pm 2.3^{*}$ & $5.01 \pm 0.35$ & $3.70 \pm 0.29$ & $26.43 \pm 1.48^{*}$ \\
\hline DECF, $200 \mathrm{mg} / \mathrm{kg}$ & $29.8 \pm 3.5^{*}$ & $5.84 \pm 0.58$ & $3.88 \pm 0.43$ & $33.00 \pm 2.67^{* *}$ \\
\hline $\begin{array}{l}\text { Silybor, } 25 \mathrm{mg} / \mathrm{kg}+ \\
\text { Senadexin, } 14 \mathrm{mg} / \mathrm{kg}\end{array}$ & $40.9 \pm 4.0^{* * / /}$ & $13.69 \pm 1.38^{* / * / / /}$ & $4.43 \pm 0.51$ & $67.61 \pm 1.28^{* / * / / /}$ \\
\hline
\end{tabular}

Notes:

$1)^{*}$ - probable differences in relation to animals of the intact control group ( $\left.\mathrm{p} \leq 0.05\right)$;

2 ** - probable differences in relation to animals of the control pathology group No. 1 ( $p \leq 0.05)$;

3) \# - probable differences in relation to animals of the control pathology group No. 2 ( $\leq \leq 0.05)$.

The content of urea in the serum was determined by the diacetylmiooxime method using the standard reagent set "Urea-D (Diacetylmiooxymium with a calibrator)" HP018.01 ("Filitsit-Diagnostika", Ukraine) according to the instructions for use.

The activity of ALT was determined by the colorimetric method using the standard set of reagents "ALT-KIN (kinetic method)" HP001.02 ("Filitsit-Diagnostika", Ukraine) according to the instructions for use.

The experimental data were processed by the standard program package "Statistica 6.0" using the ANOVA (t-criterion) algorithm for dispersion analysis. Verification of samples for normality and comparative a posteriori analysis were performed within the framework of the program algorithm [23].

\section{Results and discussion}

The use of loperamide hydrochloride in the dose of $3 \mathrm{mg} / \mathrm{kg}$ for 5 days resulted in virtually identical disorders in the work of the digestive tract in healthy animals (CP-1 group) and in animals with subacute alcoholic liver damage (CP-2 group). All animals in these groups experienced functional constipation, which was reflected in a decrease in the number of bowel movements per day - indicating inhibition of the intestinal motility, and the percentage of water in fecal boluses - indicating inhibition of absorption and/or increased water secretion in the intestinal cavity ( $\mathrm{p} \leq 0.05$ versus the intact control).

When studying the effect of DECF on the defecation parameters in animals it was demonstrated that the test sample had a marked laxative effect without provoking secretory diarrhea. After application of the drug for 4 days against the background of induction of liver damage and for 5 days on the background of the introduction of loperamide all the defecation parameters studied probably did not differ from the similar values in the group of the intact control $(\mathrm{p}<0.05$, Tab. 1).
In the reference group the introduction of $\mathrm{Si}$ lybor in the dose of $25 \mathrm{mg} / \mathrm{kg}$ and Senodexin in the dose of $14 \mathrm{mg} / \mathrm{kg}$ to animals significantly changed the defecation parameters. The results obtained in this group indicate an expressive laxative effect (apparently due to Senodexin). The combined therapy in rats in the reference group significantly increased the number of defecations compared to animals of the control pathology No. 1 and control pathology No. 2 groups. At the same time, the overall average mass of fecal boluses, in particular due to the increased fluid content ( $p \leq 0.05$ versus the intact control), excessively increased. It should be noted that the fecal masses in animals of the reference group were poorly formed and difficult to separate. The signs registered in animals of the reference group indicate the constipation correction due to the development of secretory diarrhea, which is not an optimal solution to the problem of the constipation development (Tab. 1).

In the experimental study of the parameters of the gastrointestinal motility it was shown that loperamide probably suppressed motility in the small intestine and caused the retention of the fecal masses in the large intestine in the groups of the control pathology No. 1 and control pathology No. 2. It should be noted that the combination of model pathologies into a complex disorder contributed to the moderate unlikely suppression of peristalsis compared to the isolated model of constipation. This fact correlates with the literature data [10] (Tab. 2).

The use of DECF in the dose of $200 \mathrm{mg} / \mathrm{kg}$ throughout the experiment contributed to the normalization of all indicators of the intestinal motility studied, which did not statistically differ from the similar parameters in the intact control group ( $p>0.05$ ). In this case, according to the experimental data, it is obvious that the extract under research exhibits a mild laxative effect, mainly due to the improvement of the intestinal motility (Tab. 2). 


\section{Parameters of the intestinal motility ( $30 \mathrm{~min}$ ) of the experimental animals with subacute liver damage against the background of loperamide-induced constipation, $M \pm m$}

\begin{tabular}{|l|c|c|c|c|}
\hline \multicolumn{1}{|c|}{$\begin{array}{c}\text { Experimental group } \\
(\mathrm{n}=8)\end{array}$} & $\begin{array}{c}\text { The total length } \\
\text { of the small intestine, } \\
\mathrm{cm}\end{array}$ & $\begin{array}{c}\text { The distance that } \\
\text { the contrast mass } \\
\text { passed, cm }\end{array}$ & $\begin{array}{c}\text { The indicator of the } \\
\text { relative distance that } \\
\text { the contrast mass } \\
\text { passed, \% }\end{array}$ & $\begin{array}{c}\text { The number of fecal } \\
\text { boluses in the colon }\end{array}$ \\
\hline Intact control & $102.34 \pm 2.87$ & $71.41 \pm 3.48$ & $69.70 \pm 2.66$ & $4.00 \pm 0.60$ \\
\hline Control pathology No. 1 & $100.35 \pm 2.95$ & $54.66 \pm 2.41^{*}$ & $54.41 \pm 1.50^{*}$ & $6.63 \pm 0.60^{*}$ \\
\hline Control pathology No. 2 & $104.25 \pm 3.82$ & $50.25 \pm 2.15^{*}$ & $48.33 \pm 1.57^{*}$ & $5.88 \pm 0.58^{*}$ \\
\hline DECF, $200 \mathrm{mg} / \mathrm{kg}$ & $100.63 \pm 2.95$ & $68.51 \pm 4.32^{* * / \#}$ & $67.91 \pm 3.33^{* * / \#}$ & $3.63 \pm 0.50^{* * / \#}$ \\
\hline $\begin{array}{l}\text { Silybor, } 25 \mathrm{mg} / \mathrm{kg}+ \\
\text { Senadexin, } 14 \mathrm{mg} / \mathrm{kg}\end{array}$ & $103.50 \pm 2.93$ & $63.65 \pm 3.27^{* * / \#}$ & $61.58 \pm 2.84^{* / * * / \#}$ & $1.88 \pm 0.40^{* / * * / \#}$ \\
\hline
\end{tabular}

Notes:

$1)^{*}$ - probable differences in relation to animals of the intact control group $(p \leq 0.05)$;

$2{ }^{* *}$ - probable differences in relation to animals of the control pathology group No. $1(p \leq 0.05)$;

3 ) \# - probable differences in relation to animals of the control pathology group No. 2 ( $p \leq 0.05)$.

The combined therapy with a hepatoprotector and Senadexin also contributed to the improvement of the gastrointestinal motility. However, at the same time, the average indicator of the relative distance that the contrast mass passed through the small intestine was less than in the intact control, and a significantly smaller number of residual fecal boluses in the lumen of the large intestine were recorded. On the one hand, it may indicate episodic diarrhea against the background of motility inhibition in the small intestine, which is observed in some patients with liver cirrhosis [10]. On the other hand, the less motility of the small intestine may be due to the development of manifestations of tolerance to sennosides, and it is a characteristic feature of the long-term therapy. In addition, the probable cause may be an increase in the content of loperamide in the blood because of greater depression of the liver function. In any case, the mitigating effect of this therapy was characterized by the increased secretion and decreased reabsorption of the fluid in the large intestine; thus, secretory diarrhea (by the ac- tion of Senodexin) compensated for constipation. This was indicated by the most probable decrease in the number of fecal boluses in the lumen of the large intestine, even compared to the intact animals $(p \leq 0.05)$, among all groups. In addition, it should be noted that the fecal masses in the large intestine of the reference group was amorphous, poorly textured and formed; they were separated only by peristalsis zones, which was also a functional sign of diarrhea (Tab. 2).

When studying the functional state of the liver by biochemical indicators it was demonstrated that double pathology contributed to a significant disorder of the protein synthesizing and detoxifying functions of the liver, which in turn, led to hepatocyte cytolysis. It should be noted that the use of loperamide in the isolated control pathology group No. 1 did not lead to these severe disorders of the liver, but the urea content in the serum of these animals was significantly higher than in the intact control $(\mathrm{p} \leq 0.05)$. The experimental data obtained correlate with the data concerning the partial excretion of

Table 3

The content of markers of the general functional state of the liver in the serum of rats with subacute liver damage against the background of loperamide-induced constipation, $M \pm m$

\begin{tabular}{|l|c|c|c|}
\hline \multicolumn{1}{|c|}{ Experimental group $(\mathrm{n}=8)$} & Total protein, $\mathrm{g} / \mathrm{L}$ & Urea, $\mathrm{mmol} / \mathrm{L}$ & ALT, $\mathrm{mkkat} / \mathrm{L}$ \\
\hline Intact control & $73.14 \pm 4.10$ & $6.78 \pm 0.32$ & $0.61 \pm 0.03$ \\
\hline Control pathology No. 1 & $65.10 \pm 2.44$ & $8.35 \pm 0.21^{*}$ & $0.63 \pm 0.06$ \\
\hline Control pathology No. 2 & $57.28 \pm 1.68^{* / * *}$ & $13.92 \pm 0.53^{* / * *}$ & $1.55 \pm 0.10^{* / * *}$ \\
\hline DECF, $200 \mathrm{mg} / \mathrm{kg}$ & $68.65 \pm 2.41^{\#}$ & $9.18 \pm 0.69^{* / / \#}$ & $0.93 \pm 0.08^{* / * * / /}$ \\
\hline Silybor, $25 \mathrm{mg} / \mathrm{kg}+$ Senadexin, $14 \mathrm{mg} / \mathrm{kg}$ & $66.08 \pm 2.23^{\#}$ & $10.93 \pm 0.60^{* / * * / \#}$ & $1.10 \pm 0.09^{* / * * / \#}$ \\
\hline
\end{tabular}

Notes:

1) * - probable differences in relation to animals of the intact control group $(p \leq 0.05)$;

2) ${ }^{*}$ - probable differences in relation to animals of the control pathology group No. $1(p \leq 0.05)$;

3) \# - probable differences in relation to animals of the control pathology group No. $2(p \leq 0.05)$. 
urea with feces and sweat (in addition to the main pathway - with urine) [24]; thus, the total rate of its excretion can decrease due to constipation (Tab. 3).

The combined therapy and monotherapy with DECF probably contributed to the improvement of the functional state of the liver, which was mediated through positive changes in the content of markers of liver damage in the serum $(p \leq 0.05$ versus the control pathology No. 2). However, it should be noted that the hepatoprotective effect of DECF in the dose of $200 \mathrm{mg} / \mathrm{kg}$ was more pronounced than in the reference group, and it was already shown in the previous experimental studies of hepatoprotective properties of different doses of the extract compared to Silybor in the dose of $25 \mathrm{mg} / \mathrm{kg}$.

CONCLUSIONS

Thus, the experimental data obtained indicate the presence of a soft laxative effect that occurs by intensifying the intestinal motility, as well as the pronounced hepatoprotective action in the dry ex- tract from Prunus Domestica fruits containing fibers in the dose of $200 \mathrm{mg} / \mathrm{kg}$. These effects of DECF were revealed when using it in the treatment of constipation against the background of the experimental subacute liver damage, and were not inferior, and in some cases even surpassed, the effects studied in the complex application of the hepatoprotective and laxative reference drugs. It is important that DECF in its laxative effect, in contrast to Senodexin, did not cause signs of diarrhea in animals, which could be a beneficial feature of this drug for further clinical application. This herbal extract has shown that it can become a promising alternative to the single-stage complex therapy with plant hepatoprotectors and laxatives; it will avoid polypragmasy in the treatment of comorbid conditions in gastroenterology associated with diseases of the liver and congestive intestinal phenomena.

Conflict of interests: authors have no conflict of interests to declare.

\section{References}

1. Гарник, Т. П. Сучасні технології виробництва фітозасобів та перспективи фітотерапії / Т. П. Гарник // Фітотерапія. Часопис. - 2008. - № 1. - С. 59-63.

2. Dietary Natural Products for Prevention and Treatment of Liver Cancer / Y. Zhou, Y. Li, T. Zhou et al. // Nutrients. - 2016. № 3. - P. 156. https://doi.org/10.3390/nu8030156

3. Identification of a flavonoid isolated from plum (Prunus domestica) as a potent inhibitor of hepatitis C virus entry / M. Bose, M. Kamra, R. Mullick et al. // Sci Rep. - 2017. - Vol. 1. - P. 3965. https://doi.org/10.1038/s41598-017-04358-5

4. Упир, Л. В. Слива: в кн. Фармацевтична енциклопедія / голова ред. ради та автор передмови В. П. Черних. - 2-ге вид., перероб. і доп. - К. : «МOPIOH», 2010. - 1290 c.

5. Mohammed Shahm Basim. (Prunus Domestica fruits - perspective row for drugs development / Mohammed Shahm Basim, L. V. Lenchik, N. B. Caidov // Nauka i innovaciya. Seriya estestvennyh nauk. - 2017. - № 4. - P. 42-48.

6. Upyr, T. Phytochemical and pharmacological study of polysaccharide complexes of Prunus Domestica fruit / T. Upyr, Shahm Basim Mohammed, Bashar Al-Jabbar Ali Sahlani, L. Lenchyk, I. Senyuk // Sci.c J. «ScienceRise: Pharmaceutical Science». 2018. - № 3 (13) - P. 32-37. https://doi.org/10.15587/2519-4852.2018.135825

7. Celik, F. Determination of phenolic compounds, antioxidant capacity and organic acids contents of Prunus domestica L., Prunus cerasifera Ehrh. and Prunus spinosa L. fruits by HPLC / F. Celik // Acta Chromatographica. - 2017. - № 29 (4). - P. 507-510. http://doi.org/10.1556/1326.2017.00327.

8. Сенюк, I. В. Вивчення послаблюючої активності різних субстанцій, одержаних з плодів сливи домашньої Prunus domestica / I. В. Сенюк, Башар Джаббар Алі-Сахлані, Л. В. Ленчик // Укр. біофармац. журн. - 2017. - № 5 (52). - С. 21-25. https://doi.org/10.24959/ubphj.17.134

9. Сенюк, I. В. Вивчення гепатопротекторної дії екстрактів із плодів сливи домашньої / І. В. Сенюк, Башар Джабар Аль Сахлані, Мохаммед Шахм Басім // Фармацевтичний часопис. - 2018. - № 4. - C. 57-61. https://doi.org/10.11603/23120967.2018.4.9692

10. Kalaitzakis, E. Gastrointestinal dysfunction in liver cirrhosis / E. Kalaitzakis // World J. of Gastroenterol. - 2014. - Vol. 20 (40). - P. 14686-14695. https://doi.org/10.3748/wjg.v20.i40.14686

11. Scalera, A. What does irritable bowel syndrome share with non-alcoholic fatty liver disease? / A. Scalera, M. N. Di Minno, G. Tarantino // World J. of Gastroenterol. - 2013. - Vol. 19, Issue 33. - P. 5402-5420. https://doi.org/10.3748/wjg.v19. i33.5402

12. Yoon, E. Acetaminophen-Induced Hepatotoxicity : a Comprehensive Update / E. Yoon, A. Babar, M. Choudhary, M. Kutner, N. Pyrsopoulos // J. of Clinical and Translational Hepatol. - 2016. - Vol. 4 (2). - P. 131-142. https://doi.org/10.14218/ jcth.2015.00052

13. Relationship between patterns of alcohol consumption and gastrointestinal symptoms among patients with irritable bowel syndrome / K. W. Reding, K. C. Cain, M. E. Jarrett, M. D. Eugenio, M. M. Heitkemper // The American J. of Gastroenterol. - 2013. - Vol. 108, Issue 2. - P. 270-276. https://doi.org/10.1038/ajg.2012.414

14. Доклинические исследования лекарственных средств : метод. рек. / под ред. А. В. Стефанова. - К. : Авиценна, 2002. $-528 \mathrm{c}$.

15. Біохімічна оцінка результатів експериментальної терапії хронічного гепатиту фітозасобом на основі екстракту артишоку та порошку часнику / А. Таттіс, І. А. Зупанець, С. К. Шебеко та ін. // Ліки України Плюс. - 2016. - № 3 (28). - C. 63-67.

16. Pattern of alcohol consumption and its effect on gastrointestinal symptoms in inflammatory bowel disease / G. R. Swanson, S. Sedghi, A. Farhadi, A. Keshavarzian // Alcohol (Fayetteville, N.Y.). - 2010. - Vol. 44, Issue 3. - P. 223-228. https://doi. org/10.1016/j.alcohol.2009.10.019 
17. Laxative effects of fermented rice extract in rats with loperamide-induced constipation / J. S. Choi, J. W. Kim, H. R. Cho et al. // Experimental and Therapeutic Medicine. - 2014. - Vol. 8, Issue 6. - P. 1847-1854. https://doi.org/10.3892/etm.2014.2030

18. Wintola, O. A. The effect of Aloe ferox Mill. in the treatment of loperamide-induced constipation in Wistar rats / O. A. Wintola, T. O. Sunmonu, A. J. Afolayan // BMC Gastroenterol. - 2010. - Vol. 10. - P. 95. https://doi.org/10.1186/1471-230x-10-95

19. Дроговоз, С. М. Експериментальне обгрунтування альтернативи вибору гепатопротекторів / С. М. Дроговоз, Т. В. Бородина, Л. В. Деримедвідь // Ліки. - 1998. - № 5. - С. 32-35.

20. Nair, A. B. A simple practice guide for dose conversion between animals and human / A. B. Nair, S. Jacob // J. of Basic and Clinical Pharmacy. - 2016. - Vol. 7, Issue 2. - P. 27-31. https://doi.org/10.4103/0976-0105.177703

21. Gnjidic, D. Assessing medication burden and polypharmacy: finding the perfect measure / D. Gnjidic, M. Tinetti, H. G. Allore // Expert Rev. of Clinical Pharmacol. - 2017. - Vol. 10, Issue 4. - P. 345-347. https://doi.org/10.1080/17512433.2017.1301206

22. Sagar, L. Evaluation of antimotility effect of Lantana camara L. var. acuelata constituents on neostigmine induced gastrointestinal transit in mice / L. Sagar, R. Sehgal, S. Ojha // BMC Complement Altern Med. - 2005. - Vol. 5 (1). - P. 18. https://doi. org/10.1186/1472-6882-5-18

23. Халафян, А. А. STATISTICA 6. Статистический анализ данных: учебник. - 3-е изд. / А. А. Халафян. - М. : 000 «БиномПресс», 2007. - 512 c.

24. Levitt, D. G. A model of blood-ammonia homeostasis based on a quantitative analysis of nitrogen metabolism in the multiple organs involved in the production, catabolism, and excretion of ammonia in humans / D. G. Levitt, M. D. Levitt // Clinical and Experimental Gastroenterol. - 2018. - Vol. 11. - P. 193-215. https://doi.org/10.2147/ceg.s160921

25. Deacon, R. M. Housing, husbandry and handling of rodents for behavioral experiments / R. M. Deacon // Nature Protocols. - 2006. - Vol. 1 (2). - P. 936-946. https://doi.org/10.1038/nprot.2006.120

\section{References}

1. Garny`k, T. P. (2008). Fitoterapiya. Chasopy`s, 1, 59-63.

2. Zhou, Y., Li, Y., Zhou, T., Zheng, J., Li, S., \& Li, H.-B. (2016). Dietary Natural Products for Prevention and Treatment of Liver Cancer. Nutrients, 8(3), 156. https://doi.org/10.3390/nu8030156

3. Bose, M., Kamra, M., Mullick, R., Bhattacharya, S., Das, S., \& Karande, A. A. (2017). Identification of a flavonoid isolated from plum (Prunus domestica) as a potent inhibitor of Hepatitis C virus entry. Scientific Reports, 7(1). https://doi.org/10.1038/ s41598-017-04358-5

4. Upy`r, L. V. (2010). Sly`va: Farmacevty`chna ency `klopediya. Kyiv: Morion, 1290.

5. Mohammed Shahm Basim, Lenchik, L. V., Caidov, N. B. (2017). (Prunus Domestica fruits - perspective row for drugs development. Nauka i innovaciya. Seriya estestvennyh nauk, 4, 42-48.

6. Upyr, T., Basim Mohammed, S., Bashar, A.-J. A. S., Lenchyk, L., Senyuk, I., \& Kyslychenko, V. (2018). Phytochemical and pharmacological study of polysaccharide complexes of prunus domestica fruit. ScienceRise: Pharmaceutical Science, 3 (13), 32-37. https://doi.org/10.15587/2519-4852.2018.135825

7. Celik, F. (2017). Determination of phenolic compounds, antioxidant capacity and organic acids contents of Prunus domestica L., Prunus cerasifera Ehrh. and Prunus spinosa L. fruits by HPLC. Acta Chromatographica, 29(4), 507-510. http://doi. org/10.1556/1326.2017.00327

8. Senyuk, I., Bashar, A., \& Lenchyk, L. (2017). Investigation of different substances catharic properties made from Prunus domestica. Ukraïns'kij Bìfarmacevtičnij Žurnal, 5(52), 21-25. https://doi.org/10.24959/ubphj.17.134

9. Senjuk, I. V., Al Sahlani, B. J., \& Basim, M. S. (2018). Farmacevty`chny`j chasopy`s, 4, 57-61. https://doi.org/10.11603/23120967.2018.4.9692

10. Kalaitzakis, E. (2014). Gastrointestinal dysfunction in liver cirrhosis. World Journal of Gastroenterology, 20(40), 14686. https://doi.org/10.3748/wjg.v20.i40.14686

11. Scalera, A., Di Minno, M. N., Tarantino, G. (2013). What does irritable bowel syndrome share with non-alcoholic fatty liver disease? World journal of gastroenterology, 19(33), 5402-5420. https://doi.org/10.3748/wjg.v19.i33.5402

12. Yoon, E., Babar, A., Choudhary, M., Kutner, M., Pyrsopoulos, N. (2016). Acetaminophen-Induced Hepatotoxicity: a Comprehensive Update. Journal of clinical and translational hepatology, 4 (2), 131-142. https://doi.org/10.14218/jcth.2015.00052

13. Reding, K. W., Cain, K. C., Jarrett, M. E., Eugenio, M. D., \& Heitkemper, M. M. (2013). Relationship Between Patterns of Alcohol Consumption and Gastrointestinal Symptoms Among Patients With Irritable Bowel Syndrome. The American Journal of Gastroenterology, 108(2), 270-276. https://doi.org/10.1038/ajg.2012.414

14. Stefanov, O. V. (2001). Doklinichni doslidzhennia likarskykh zasobiv. Kyiv: Avitsena, 528.

15. Tattis, A., Zupanecz’, I. A., Shebeko, S. K., Otrishko, I. A., Grinczov, Ye. F. (2016). Liky` Ukrayiny` Plyus, 3 (28), $63-67$.

16. Swanson, G. R., Sedghi, S., Farhadi, A., \& Keshavarzian, A. (2010). Pattern of alcohol consumption and its effect on gastrointestinal symptoms in inflammatory bowel disease. Alcohol, 44(3), 223-228. https://doi.org/10.1016/j.alcohol.2009.10.019

17. Choi, J.-S., Kim, J. W., Cho, H.-R., Kim, K.-Y., Lee, J.-K., Sohn, J. H., \& Ku, S.-K. (2014). Laxative effects of fermented rice extract in rats with loperamide-induced constipation. Experimental and Therapeutic Medicine, 8(6), 1847-1854. https://doi. org/10.3892/etm.2014.2030

18. Wintola, O. A., Sunmonu, T. O., Afolayan, A. J. (2010). The effect of Aloe ferox Mill. in the treatment of loperamide-induced constipation in Wistar rats. BMC gastroenterology, 10, 95. https://doi.org/10.1186/1471-230x-10-95

19. Drogovoz, S. M., Borody`na, T. V., Dery`medvid’, L. V. (1998). Liky`, 5, 32-35.

20. Nair, A. B., Jacob, S. (2016). A simple practice guide for dose conversion between animals and human. Journal of basic and clinical pharmacy, 7(2), 27-31. https://doi.org/10.4103/0976-0105.177703

21. Gnjidic, D., Tinetti, M., Allore, H. G. (2017). Assessing medication burden and polypharmacy: finding the perfect measure. Expert review of clinical pharmacology, 10(4), 345-347. https://doi.org/10.1080/17512433.2017.1301206 
22. Sagar, L., Sehgal, R., \& Ojha, S. (2005). Evaluation of antimotility effect of Lantana camara L. var. acuelata constituents on neostigmine induced gastrointestinal transit in mice. BMC Complementary and Alternative Medicine, 5(1), 18. https://doi. org/10.1186/1472-6882-5-18

23. Khalafian, A. A. (2007). STATISTICA 6. Statisticheskii analiz dannykh. Uchebnik. Moscow: 000 «Binom-Press», 512.

24. Levitt, D., \& Levitt, M. (2018). A model of blood-ammonia homeostasis based on a quantitative analysis of nitrogen metabolism in the multiple organs involved in the production, catabolism, and excretion of ammonia in humans. Clinical and Experimental Gastroenterology, 11, 193-215. https://doi.org/10.2147/ceg.s160921

25. Deacon, R. M. (2006). Housing, husbandry and handling of rodents for behavioral experiments. Nature Protocols, 1 (2), P. 936-946. https://doi.org/10.1038/nprot.2006.120.

Information about authors / Відомості про авторів / Сведения об авторах

Bashar Jabbar Ali Al-Sahlanee, postgraduate student of the Department of Biological Chemistry, National University of Pharmacy.

E-mail: al.sahlny82@yahho.com

Башар Джабар Алі Аль-Сахлані, аспірант кафедри біологічної хімії, Національний фармацевтичний університет. Е-таіl:

al.sahlny82@yahho.com

Башар Джабар Али Аль-Сахлани, аспирант кафедры биологической химии, Национальный фармацевтический университет.

E-mail: al.sahlny82@yahho.com

Lytkin D. V., head of the Central Research Laboratory, National University of Pharmacy. E-mail: d.v.lytkin@gmail.com

Литкін Д. В., завідувач Центральної науково-дослідної лабораторії, Національний фармацевтичний університет.

E-mail: d.v.lytkin@gmail.com

Лыткин Д. В., заведующий Центральной научно-исследовательской лабораторией, Национальный фармацевтический университет, E-mail:d.v.lytkin@gmail.com

Senyuk I. V., Candidate of Pharmacy (Ph.D.), associate professor of the Department of Biological Chemistry, National University of Pharmacy. E-mail: citochrom@gmail.com

Сенюк I. B., кандидат фармацевтичних наук, доцент кафедри біологічної хімії, Національний фармацевтичний університет. E-mail: citochrom@gmail.com

Сенюк И. В., кандидат фармацевтических наук, доцент кафедры биологической химии, Национальный фармацевтический университет. E-mail: citochrom@gmail.com

Mailing address: 12, Kulikovska str., Kharkiv, 61002, Ukraine, Department of Biological Chemistry, National University of Pharmacy.

Tel.: +380631313100

Адреса для листування: 61002, м. Харків, вул. Куликівська, 12, кафедра біологічної хімії НФаУ. Тел.: +380631313100.

Адрес для переписки: 61002, г. Харьков, ул. Куликовская, 12, кафедра биологической химии НФаУ. Тел.: +380631313100. 